MAXTed, W. R. (1955). J. gen. Microbiol. 12, 484-495

\title{
The Influence of Bacteriophage on Streptococcus pyogenes
}

\author{
BY W. R. MAXTED \\ Streptococcus Reference Laboratory, Central Public Health Laboratory, \\ Colindale, London, N.W. 9
}

SUMMARY : By the selective action of certain bacteriophages on cultures of susceptible streptococei it is possible to alter or enhance certain of their characteristics. The extractable $M$ antigen may be greatly increased; non-mucoid strains may become completely mucoid with or without the increase in $M$ antigen. Some phageselected cultures have shown a marked increase in mouse virulence and some an ability to survive in normal human blood not possessed by the parent strain.

Despite the great amount of work published on bacteriophages, the only extensive studies on those active against group $\mathbf{A}$ haemolytic streptococci are those by Evans (e.g. 1933, 1934, 1940) and Evans \& Sockrider (1942). In preliminary work with phages obtained from sewage and sent to us by Professor Boulgakov of Paris, it was found that lysis was often much more readily obtained when the test was carried out in the presence of hyaluronidase (Maxted, 1952). It was also noted that the colonies of the secondary growth that appeared after vigorous lysis had taken place were often very mucoid when plated on to glucose serum agar, even when the parent strain had never shown mucoid variants upon preliminary plating. The secondary growth from one strain also showed increased $\mathbf{M}$ antigen content, and an ability to survive in human blood not possessed by the parent strain. A more detailed investigation was therefore made of the changes in antigenic structure, colonial appearance and virulence that are produced in cultures by passage through phage-containing media.

\section{MATERIAL AND METHODS}

Preparation of hyaluronidase. Minced bull testicle was extracted overnight in the cold with $\mathrm{N} / 1$ acetic acid, neutralized, and the supernatant fluid Seitzfiltered.

Source and propagation of phages. The phages used were derived from those isolated by Professor Boulgakov from Paris sewage; they were propagated in nutrient broth containing hyaluronidase, each on its particular strain of streptococcus. The phages are designated A1, A6, A12 and A 25. The letter indicates the Lancefield group to which the propagating strain belongs and the number the type. The phages are not specific for their propagating type strain.

For the phage passage experiments with types 3 and 27 the phage A1 was adapted to these strains; for the experiments with the type 5 strain phage A6 was similarly adapted. A mixture of all four of the original phages was used for the serial transfers of strain 1506 type 30 . 
Serial phage passage. Two separate $5 \mathrm{ml}$. amounts of nutrient broth, containing $3 \%$ of crude hyaluronidase extract, were inoculated with a loopful of $18 \mathrm{hr}$. Todd-Hewitt broth culture. To one tube, $\mathbf{0 . 0 2} \mathrm{ml}$. of the appropriate phage filtrate was added, the other acted as a control and both tubes were then incubated overnight. Each was subcultured into fresh hyaluronidase broth and on to serum glucose agar. This procedure was repeated as often as necessary.

Phage survivor. The term phage survivor was applied to those strains which had survived passage through broth containing both phage and hyaluronidase, in tests in which strong and visible lysis had taken place. When transferred to Todd-Hewitt broth in the absence of hyaluronidase, they grew vigorously. They were not necessarily resistant to phage when grown under conditions most favourable to phage action.

Detection of mucoid colonies. The presence of mucoid colonies was determined in 15-18 hr. cultures on nutrient agar containing $0.5 \%$ glucose and $5 \%$ horse serum. On such a medium many streptococci form somewhat mucoid colonies, but except for certain serological types (e.g. 17, 18, 19 and 24) they do not ordinarily produce the 'grossly mucoid' colonies characteristic of many of the strains that survive phage passage.

Estimation of hyaluronic acid. Samples of broth supernatant from cultures grown in Hartley digest broth with $3 \%$ maltose added were tested every $24 \mathrm{hr}$. over a 4-day period. Estimations of hyaluronic acid were by the acidified serum turbidimetric method (Faber \& Rosendal, 1954). Commercial potassium hyaluronate was used for the standard hyaluronic acid solution.

Detection of type antigens. Cultures grown in $50 \mathrm{ml}$. amounts of buffered glucose broth were centrifuged and the deposit extracted with hot acid, neutralized, and tested in capillary tubes against specific antisera (Swift, Wilson \& Lancefield, 1943). Agglutination tests for $\mathbf{T}$ antigen were carried out on suspensions grown at $30^{\circ}$ in a buffered glucose broth, and digested with pancreatic extract to render them smooth and to destroy the $\mathbf{M}$ antigen.

The antisera for both the precipitation and agglutination tests were those used for routine type identification of streptococci, and prepared by the recognized techniques of Swift et al. (1943) and Griffith (1934).

Estimation of mouse virulence. Tenfold dilutions of overnight cultures, grown in a buffered glucose broth, were inoculated intraperitoneally, in $0.5 \mathrm{ml}$. amounts, into mice which were subsequently observed for 10 days.

Bactericidal tests. Tubes $\left(2 \times \frac{1}{2}\right.$ in.) containing $0.3 \mathrm{ml}$. of normal heparinized human blood were inoculated with $0.02 \mathrm{ml}$. of suitable dilutions (usually $10^{-3}$ and $10^{-5}$ ) of the culture under test. With the higher dilution the inoculum usually contained between 30 and 100 viable units. The tubes were corked and incubated at $37^{\circ}$, being shaken mechanically for $3 \mathrm{~min}$. every $15 \mathrm{~min}$. Explants were made in duplicate at 3 and $20 \mathrm{hr}$. over one-sixth of a $10 \mathrm{~cm}$. diam. blood agar plate, using a standard loop throughout. The growth was recorded as \pm to ++++ .

Source of strains. Strain T5B (type 5), S43 (type 6) and SF 40 (type 27) were from the original Griffith collection. Strain Richards (type 3) came from a case of puerperal fever; strains J.L., 927, 1518, 1608 and 1130 are all recently 
isolated strains of type 12; J.L. and 1518 were isolated from the throats of patients with acute nephritis, 1608 and 1130 from cases of tonsillitis and 927 from the throat of a symptomless carrier. Strain 1506 (type 30) was isolated from the throat of a child in a rheumatic fever convalescent home.

\section{RESULTS}

\section{Colonial change after phage passage}

With some strains of Streptococcus pyogenes the phages produced no change in colonial appearance, but, provided their lytic action was strong, many strains showed a profound change to a grossly mucoid colony form (Pl. 1, fig. 1). The investigations reported here have been concerned very largely with the strains which showed this change.

Of 50 non-mucoid strains of streptococci examined for phage survivors, 36 yielded mucoid variants. These 36 strains were distributed over 13 different types.

Strains which normally tend to yield mixtures of mucoid and non-mucoid colonies usually yielded none but mucoid colonies after phage passage. The latter were often larger and remained raised and moist on a solid medium longer than mucoid colonies selected visually from the mixed parent strain. The change after phage passage is most striking with strains that ordinarily show no mucoid colonies on culture, such as the strain 1130 (type 12) which has been used in many of the experiments described.

Table 1. Hyaluronic acid in the supernatant fluid of cultures of phagepassaged strains and their non-mucoid parent strains

\begin{tabular}{|c|c|c|c|c|c|c|}
\hline \multirow[b]{2}{*}{ Strain } & \multirow[b]{2}{*}{ Type } & \multirow[b]{3}{*}{$\begin{array}{l}\text { Parent } \\
\text { Phage survivor }\end{array}$} & \multicolumn{4}{|c|}{ Hyaluronic acid, mg./ml., after incubation for } \\
\hline & & & $24 \mathrm{hr}$. & $48 \mathrm{hr}$. & $72 \mathrm{hr}$ & $96 \mathrm{hr}$. \\
\hline T5 B & 5 & & $\begin{array}{l}0 \\
0 \cdot 3\end{array}$ & $\begin{array}{l}0 \\
0 \cdot 26\end{array}$ & $\begin{array}{l}0 \\
0 \cdot 16\end{array}$ & $\begin{array}{l}0 \\
0 \cdot 02\end{array}$ \\
\hline $\mathbf{S} 4 \mathbf{3}$ & 6 & $\begin{array}{l}\text { Parent } \\
\text { Phage survivor }\end{array}$ & $\begin{array}{l}0 \\
0 \cdot 27\end{array}$ & $\begin{array}{l}0 \\
0 \cdot 27\end{array}$ & $\begin{array}{l}\mathbf{0} \\
\mathbf{0} \cdot \mathbf{3 1}\end{array}$ & $\begin{array}{l}0 \\
0 \cdot 3\end{array}$ \\
\hline SF 40 & 27 & $\begin{array}{l}\text { Parent } \\
\text { Phage survivor }\end{array}$ & $\begin{array}{l}0 \\
0 \cdot 21\end{array}$ & $\begin{array}{l}0 \\
0 \cdot 15\end{array}$ & $\begin{array}{l}0 \\
0.04\end{array}$ & $\begin{array}{l}\mathbf{0} \\
\mathbf{0}\end{array}$ \\
\hline 1130 matt & 12 & $\begin{array}{l}\text { Parent } \\
\text { Phage survivor }\end{array}$ & $\begin{array}{l}0 \\
0 \cdot 35\end{array}$ & $\begin{array}{l}0 \\
0 \cdot 35\end{array}$ & $\begin{array}{l}\mathbf{0} \\
\mathbf{0 \cdot 3 5}\end{array}$ & $\begin{array}{l}0 \\
0 \cdot 35\end{array}$ \\
\hline 1130 glossy & & $\begin{array}{l}\text { Parent } \\
\text { Phage survivor }\end{array}$ & $\begin{array}{l}0 \\
0 \cdot 38\end{array}$ & $\begin{array}{l}0 \\
0 \cdot 38\end{array}$ & $\begin{array}{l}0 \\
0 \cdot 41\end{array}$ & $\begin{array}{l}0 \\
0 \cdot 35\end{array}$ \\
\hline
\end{tabular}

The mucoid appearance of the colonies is probably due to increased production of the hyaluronic acid which ordinarily forms the streptococcal capsule. Thus colonies of phage-surviving mucoid variants, as well as naturally occurring mucoid variants, had non-mucoid colonies on agar containing hyaluronidase (Pl. 1, fig. 2). With all of five strains tested, the phage-survivors liberated hyaluronic acid into the medium during growth, although none was detected in cultures of their non-mucoid parent strains (Table 1). The progressive decrease in hyaluronic acid in the T5B and T 27 phage-survivor 
cultures was due to weak hyaluronidase production; none of the other strains produced detectable amounts of the enzyme.

To discover the rapidity with which the mucoid variants appeared, tubes of nutrient broth with and without phage were seeded with strain 1130 (type 12). Counts were made at intervals by plating on serum glucose agar to which phage antiserum had been added. Phage-particle counts were also made on plates previously flooded with the propagating strain for this phage. The first mucoid colonies appeared between 2 and $4 \mathrm{hr}$. (Table 2 ) and at $6 \mathrm{hr}$. the organisms present in the phage broth, though only slightly more numerous than the original inoculum, were all mucoid. The change occurred during the period of greatest phage multiplication.

Table 2. Time at which mucoid variants appeared in broth culture with phage present

\begin{tabular}{|c|c|c|c|c|c|c|}
\hline \multirow[b]{3}{*}{ Time } & \multicolumn{4}{|c|}{ Numbers of colonies/mI. } & & \multirow{3}{*}{$\begin{array}{c}\text { No. phage } \\
\text { particles/ } \\
\mathrm{ml} \times 10^{4}\end{array}$} \\
\hline & \multicolumn{2}{|c|}{ Control tube, no phage } & \multicolumn{3}{|c|}{ Broth + phage } & \\
\hline & $\begin{array}{c}\text { Non-mucoid } \\
\times 10^{4}\end{array}$ & Mucoid & $\begin{array}{r}\text { Total } \\
\times 10^{4}\end{array}$ & $\begin{array}{c}\text { Non-mucoid } \\
(\%)\end{array}$ & $\begin{array}{c}\text { Mucoid } \\
(\%)\end{array}$ & \\
\hline $15 \mathrm{~min}$. & $0 \cdot 7$ & $\mathbf{0}$ & 0.7 & 100 & $\mathbf{0}$ & $\mathbf{5}$ \\
\hline $2 \mathrm{hr}$. & 6 & 0 & 5.5 & 100 & 0 & 9 \\
\hline $4 \mathrm{hr}$ & 58 & $\mathbf{0}$ & $0 \cdot 2$ & 84 & 16 & 150 \\
\hline $6 \frac{1}{2} \mathrm{hr}$. & 320 & $\mathbf{0}$ & $1 \cdot 1$ & $\mathbf{0}$ & 100 & $\mathbf{3 1 0}$ \\
\hline $9 \mathrm{hr}$. & 240 & 0 & 15 & 0 & 100 & 300 \\
\hline
\end{tabular}

Origin of mucoid variants

Most of the non-mucoid strains which developed mucoid colony variants after phage passage were also made mucoid by passage through mice. This, and the fact that many strains of streptococci are found normally to yield a mixture of mucoid and non-mucoid colonies, suggested that the appearance of completely mucoid cultures after phage passage was probably due to selection.

In an attempt to distinguish between selection by the phages of randomly appearing mutants and the production of variants by the action of the phage, experiments were made on the lines suggested by Newcombe (1949) and by Luria \& Delbrück (1943).

In the first, three to nine $15 \mathrm{~cm}$. plates of glucose serum agar were inoculated with approximately 1500 viable units of the streptococcus under test and incubated at $37^{\circ}$ for 3-4 hr. The cells on half the plates were then redistributed by spreading $0.5 \mathrm{ml}$. of saline over the surface with a glass spreader; the other plates remained as controls. Both sets were carefully flooded with a phage filtrate known to be lytic for the streptococcus. (In other experiments it was shown that the flooding did not lead to appreciable spreading of the colonies.) After incubation the numbers of mucoid colonies on both sets of plates were counted (Table 3). In two of the four tests there were clearly more mucoid colonies on the 'spread' plates than on the 'unspread' plates, as would be expected on the supposition of a random-mutant origin for the mucoid 
variants. In the other two experiments, however, there was no noteworthy difference between the spread and unspread plates. The test could not therefore be held to give convincing evidence on the origin of the variants.

Table 3. Number of mucoid colonies developing on spread and unspread phage-impregnated plates, in four spread-plate experiments

\begin{tabular}{|c|c|c|c|c|c|c|c|c|c|c|c|c|c|}
\hline \multirow{2}{*}{$\begin{array}{l}\text { Strain } \\
\text { T 5 B }\end{array}$} & \multirow{2}{*}{$\begin{array}{c}\text { Type } \\
5\end{array}$} & \multirow{2}{*}{\multicolumn{2}{|c|}{$\begin{array}{l}\text { Colonies } \\
\text { on control } \\
\text { plate, } \\
\text { without } \\
\text { phage } \\
1600 \\
\text { Confluent }\end{array}$}} & \multicolumn{9}{|c|}{$\begin{array}{l}\text { No. of mucoid colonies on individual } \\
\text { phage-containing plates }\end{array}$} & \multirow{2}{*}{$\begin{array}{c}\text { Mean } \\
\text { no. } \\
1 \cdot 7 \\
5 \cdot 2\end{array}$} \\
\hline & & & & $\begin{array}{l}1 \\
5\end{array}$ & $\begin{array}{l}1 \\
6\end{array}$ & $\begin{array}{l}1 \\
6\end{array}$ & $\mathbf{0}$. & $\begin{array}{l}4 \\
4\end{array}$ & $\begin{array}{l}2 \\
7\end{array}$ & $\begin{array}{l}1 \\
6\end{array}$ & $\begin{array}{l}3 \\
1\end{array}$ & $\begin{array}{r}2 \\
11\end{array}$ & \\
\hline SF 40 & 27 & $\begin{array}{l}\text { Control } \\
\text { Spread }\end{array}$ & $\begin{array}{l}2000 \\
\text { Confluent }\end{array}$ & $\begin{array}{l}\mathbf{5} \\
0\end{array}$ & $\begin{array}{l}3 \\
6\end{array}$ & $\begin{array}{l}4 \\
\mathbf{3}\end{array}$ & $\begin{array}{l}3 \\
5\end{array}$ & $\begin{array}{l}4 \\
2\end{array}$ & $\begin{array}{l}2 \\
6\end{array}$ & $\begin{array}{l}6 \\
7\end{array}$ & $\begin{array}{l}\mathbf{5} \\
\mathbf{0}\end{array}$ & • & $\begin{array}{l}4 \cdot 0 \\
3 \cdot 6\end{array}$ \\
\hline 1 matt & 12 & $\begin{array}{l}\text { Control } \\
\text { Spread }\end{array}$ & $\begin{array}{l}1500 \\
\text { Confluent }\end{array}$ & $\begin{array}{r}10 \\
5\end{array}$ & $\begin{array}{r}9 \\
12\end{array}$ & $\begin{array}{l}14 \\
16\end{array}$ & $\begin{array}{l}6 \\
7\end{array}$ & $\begin{array}{r}11 \\
6\end{array}$ & $\dot{\cdot}$ & . & $\dot{\cdot}$ & $\cdot$ & $\begin{array}{r}10 \cdot 0 \\
9 \cdot 2\end{array}$ \\
\hline 2 matt & 12 & $\begin{array}{l}\text { Control } \\
\text { Spread }\end{array}$ & $\begin{array}{l}1200 \\
\text { Confluent }\end{array}$ & $\begin{array}{l}0 \\
7\end{array}$ & $\begin{array}{r}0 \\
11\end{array}$ & $\begin{array}{l}1 \\
6\end{array}$ & · & . & . & . & . & · & $\begin{array}{l}0 \cdot 3 \\
8 \cdot 0\end{array}$ \\
\hline
\end{tabular}

Two strains were submitted to Luria \& Delbrück's fluctuation tests. Twelve $5 \mathrm{ml}$. broth tubes were inoculated with $0.02 \mathrm{ml}$. samples of the culture previously diluted $10^{-3}$, and incubated for $3-4 \frac{1}{2} \mathrm{hr}$. Single $0.4 \mathrm{ml}$. samples from each tube were then transferred to glucose serum agar plates containing sufficient phage to prevent the development of non-mucoid colonies. Twelve similar samples were taken from one of the tubes (Table 4). As with the Newcombe spread-plate experiments there was a suggestion that the results supported the random-mutant hypothesis, A larger experiment was carried out with a third strain, 1608, and the inoculum was allowed to grow over a longer period ( $8 \mathrm{hr}$.) before the samples were taken. The difference between the variance and the mean in this test seemed conclusive evidence in favour of the random mutation hypothesis.

\section{Table 4. Results of fluctuation tests}

\begin{tabular}{|c|c|c|c|c|c|c|c|c|c|c|}
\hline \multirow[b]{2}{*}{ Strain } & \multirow[b]{2}{*}{ Type } & \multirow{2}{*}{$\begin{array}{c}\text { No. of } \\
\text { samples }\end{array}$} & \multicolumn{4}{|c|}{$\begin{array}{c}\text { Samples from independent } \\
\text { cultures }\end{array}$} & \multicolumn{4}{|c|}{ Samples from single cultures } \\
\hline & & & Mean & Variance & $\chi^{2}$ & $\boldsymbol{P}$ & Mean & Variance & $\chi^{2}$ & $\boldsymbol{P}$ \\
\hline$\Gamma 5$ & $\mathbf{5}$ & 12 & $1 \cdot 33$ & & $21 \cdot 6$ & $<0.05$ & $0 \cdot$ & $0 \cdot($ & · & - \\
\hline F4 & 27 & 12 & $3 \cdot 75$ & $6 \cdot 39$ & 18 & & 1.75 & $2 \cdot$ & . & . \\
\hline 1608 & 12 & 39 & $11 \cdot 1$ & $64 \cdot 4$ & $2381 \cdot 3$ & $<0.001$ & $4 \cdot 1$ & $1 \cdot 2$ & $45 \cdot 7$ & $>0.0$ \\
\hline
\end{tabular}

Several attempts to demonstrate mucoid variants in a non-mucoid culture by the replica plating technique of Lederberg \& Lederberg (1952) were unsuccessful.

Some of the rather indefinite results obtained in these tests could be explained if the mucoid variants were unstable and tended to revert to the non-mucoid form. However, in numerous subcultures on plates and through 
broth this has not been observed. At the same time, the mucoid variants grow more slowly than their non-mucoid parents. Fig. 1 shows the growth rate in broth of a mucoid variant of strain 1130 obtained by mouse passage, and that of the non-mucoid parent strain. The non-mucoid strain had an advantage in mixed culture which would be enough to keep the mucoid variants down to insignificant proportions in a series of laboratory subcultures.

The fact that the streptococci grow in chains which are not easily broken up on plating may also have influenced these results. Thus multiple mutant cells in one chain can probably only give rise to single mucoid colonies, leading to

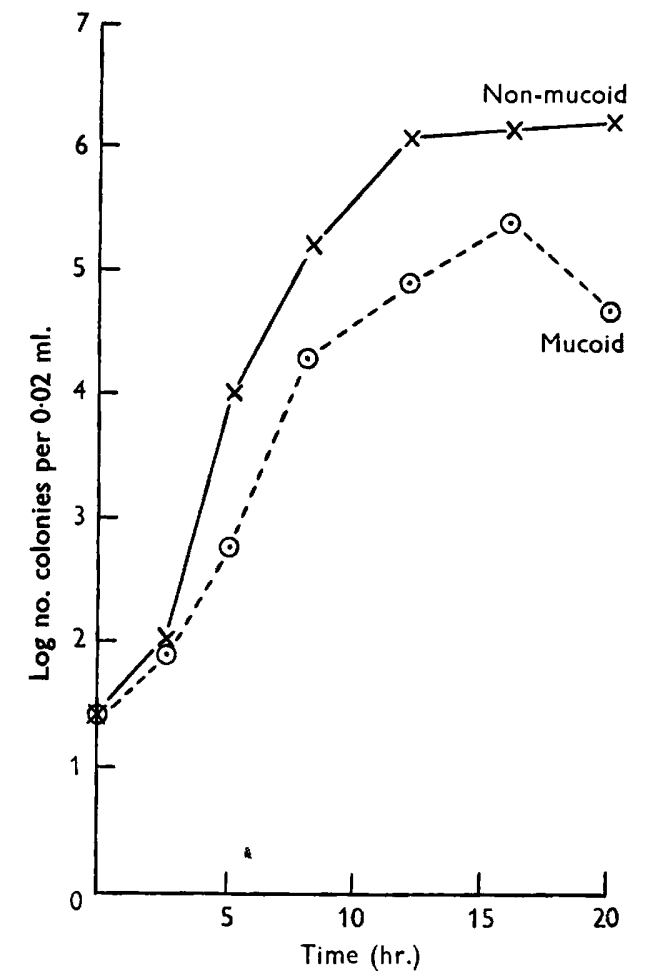

Fig. 1. Growth rate of non-mucoid and mucoid variants of strain 1130 .

a reduction in the variance observed in the fluctuation and spread-plate experiments. The mean chain length of the cultures such as were used for these experiments was 7 with a range of 3 to 17 .

\section{$M$ antigen in phage-passaged strains}

Apart from their colony form, the phage-surviving variants may also differ from their parents in $M$ antigen content, as judged by the amount of visible precipitate formed when an acid extract is mixed with an equal volume of specific antiserum in a capillary tube. 
The $M$ antigen was increased in 9 of the 10 strains most closely examined for this change (Table 5). The most striking results were with strains which had given the merest trace of $\mathbf{M}$ when first tested. Their phage survivors gave very strong $M$ reactions and the extracts could often be diluted to $1 / 64$. Even strains that had average amounts of the antigen often showed a marked increase in the amounts extracted from the phage survivors, although not all such strains became mucoid. A number of glossy variants containing no M substance were passaged through broth to which phage had been added, and though they became mucoid they showed no trace of $M$ antigen.

Table 5. Amount of $M$ antigen extracted from parent strains and their phage survivors

\begin{tabular}{|c|c|c|c|c|c|}
\hline \multirow[b]{2}{*}{ Strain } & \multirow[b]{2}{*}{ Type } & \multicolumn{2}{|c|}{ Parent strain } & \multicolumn{2}{|c|}{ Phage survivors } \\
\hline & & $\begin{array}{l}\text { Final active } \\
\text { dilution of } \\
\text { extract }\end{array}$ & $\begin{array}{c}\text { Colony } \\
\text { appearance }\end{array}$ & $\begin{array}{c}\text { Final active } \\
\text { dilution of } \\
\text { extract }\end{array}$ & $\begin{array}{c}\text { Colony } \\
\text { appearance }\end{array}$ \\
\hline Richards & $\mathbf{3}$ & $1 / 8$ & Mucoid & $1 / 64$ & Mucoid \\
\hline T 5 B & $\mathbf{5}$ & $1 / 32$ & Non-mucoid & $1 / 64$ & Mucoid \\
\hline $\mathrm{S} 43$ & 6 & $1 / 8$ & Mucoid & $1 / 32$ & Mucoid \\
\hline 927 & 12 & $1 / 16$ & Non-mucoid & $1 / 64$ & Non-mucoid \\
\hline 1518 & 12 & $1 / 16$ & Non-mucoid & $1 / 64$ & Mucoid \\
\hline 1130 matt & 12 & $1 / 16$ & Non-mucoid & $1 / 64$ & Mucoid \\
\hline 1130 glossy & 12 & Nil & Non-mucoid & Nil & Mucoid \\
\hline J.L. & 12 & Trace undiluted & Non-mucoid & $1 / 16$ & Mucoid \\
\hline 1506 & 30 & Trace undiluted & Mixed & $1 / 16$ & Mucoid \\
\hline
\end{tabular}

Again, the process seemed to be one of selection, since in no instance did we succeed in promoting $M$ antigen production by strains that failed to show any trace of it in the initial test, but the reason for the selection is not clear.

Table 6. The effect of trypsin on the phage resistance of matt $M$-containing variants

Lysis on plates spread with specified lawn and inoculated

Bacterial lawn from
broth culture of
1130 matt
1130 glossy
1130 matt + trypsin
1130 glossy + trypsin

\begin{tabular}{lcccc}
\hline Nil & $10^{-1}$ & $10^{-2}$ & $10^{-3}$ & $10^{-4}$ \\
CL & CL & +++ & - & - \\
CL & CL & CL & ++ & 50 \\
CL & CL & CL & ++ & 40 \\
CL & CL & CL & ++ & 70
\end{tabular}

$\mathbf{C L}=$ confluent lysis $;+++=$ lysis almost complete $;++=50 \%$ lysis $;+=10-50$ plaques; $\pm=$ fewer than 10 plaques.

The phage was titrated on a solid medium using either the matt-colony M-containing variant or the glossy variant, without $M$ antigen, for the lawn, and the matt strain seemed more resistant to the phage. Both variants were then grown in broth containing active trypsin to destroy the $\mathbf{M}$ antigen, and the titration was repeated on trypsin-containing plates (Table 6). The cultures 
gave identical phage titres. The increase in phage action on the matt M-containing strain when it was grown in the presence of trypsin may have been due to the destruction of the $\mathbf{M}$ antigen, but it might also have been due to the very noticeable improvement in the smoothness of the bacterial lawn.

Using these matt and glossy variants of strain 1130, viable counts were made of the survivors present after incubation for $24 \mathrm{hr}$. in broth containing phage, with and without the addition of trypsin. The matt-colony culture yielded $5 \cdot 3 \times 10^{5}$ viable organisms in the absence of trypsin and $1.3 \times 10^{3}$ in its presence; for the glossy-colony culture the counts were respectively $2 \cdot 3 \times 10^{5}$ and $3.0 \times 10^{4}$. However, this partial resistance to the action of phage by the matt-colony M-containing variants may well have been due simply to their extreme granularity in fluid and on solid media. That it was not due to $M$ antigen was also suggested by the results obtained when the parent strain of a weak M-positive culture was phage-passaged through broth with the addition of active trypsin to ensure that little or no $M$ antigen was produced during growth. The survivors of three such subcultures, when grown in trypsin-free medium and extracted, gave equally good strongly positive $M$ precipitation reactions as when phage passage was through broth without the addition of trypsin.

\section{$T$ antigens of phage-passaged strains}

The $\mathbf{T}$ antigens of group $\mathbf{A}$ streptococci are most easily identified by slide agglutination trypsin-digested suspensions. The development of the antigen is favoured by growth at $30^{\circ}$. T agglutination was tested on cultures of phage survivors from a variety of types, grown at 30 and $37^{\circ}$.

Phage survivors grown at either temperature were usually inagglutinable when smooth enough to test without trypsin digestion. After trypsin treatment all the $30^{\circ}$ suspensions reacted, although some very poorly, but a number of these grown at $37^{\circ}$ still failed to agglutinate. Streptococci containing an $\mathrm{M}$ antigen not infrequently fail to agglutinate with $\mathrm{T}$ antisera, and the failure of most of the strains grown at either temperature to react before trypsin digestion is in agreement with results obtained when testing many naturally mucoid strains of streptococci. It is recognized that a hyaluronic acid capsule interferes with agglutination.

These results support those of Schwartzman (1927), who reported that a number of strains failed to agglutinate after surviving phage action. As the benefit of incubation at a lower temperature and the effect of trypsin digestion on the suspensions had not been described, these tests were presumably done on untreated $37^{\circ}$ suspensions, and with unabsorbed sera.

\section{Virulence of phage-selected cultures}

Mouse virulence. Since an antigenic and colonial change might well be associated with an alteration in virulence, a number of phage survivors and their parent strains were tested for their mouse virulence. The parent strains had either (a) poor $\mathrm{M}$ content and mucoid colonies, $(b)$ good $\mathrm{M}$ content and 


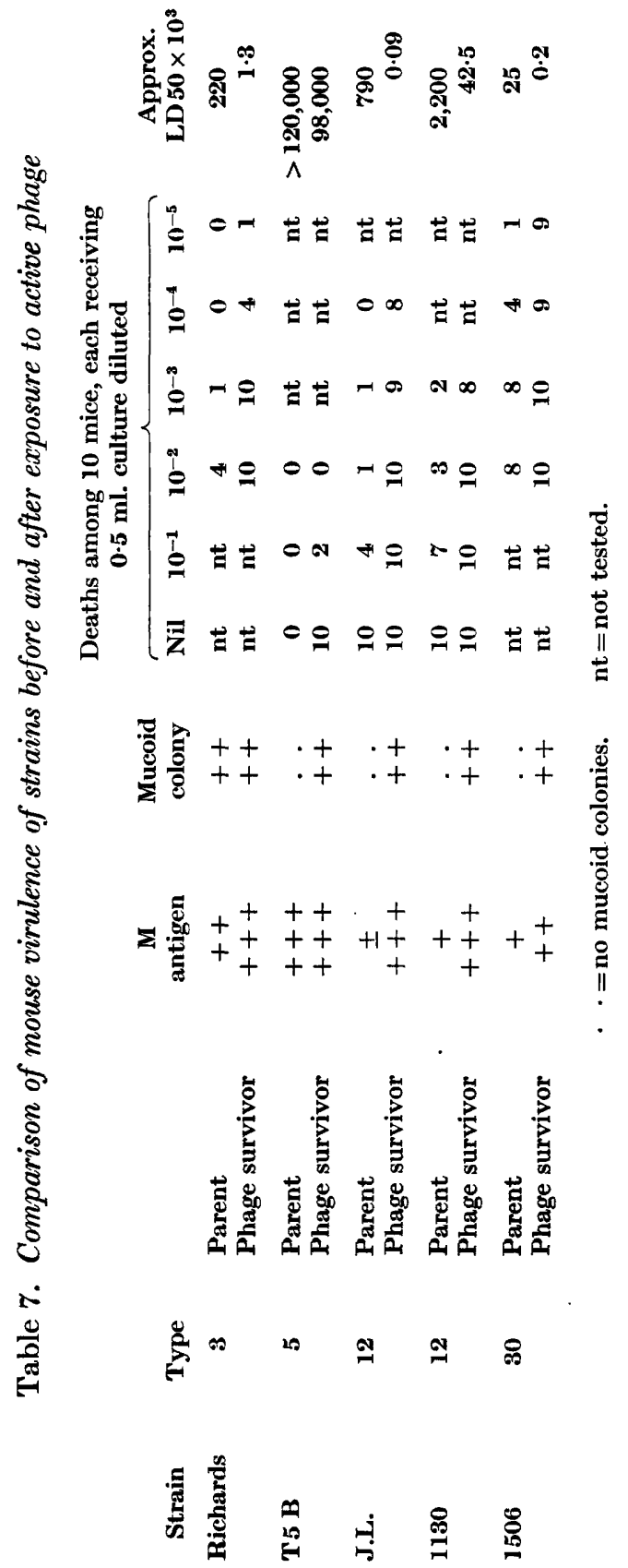


non-mucoid colonies, or $(c)$ good $M$ content and mucoid colonies; the last group were already partially virulent (Table 7 ). There was an increase in the mouse virulence of all the phage survivor strains, including 'Richards' which was already mucoid and M-reactive.

The promotion of virulence by in vitro cultivation of streptococci in such a selective system has not hitherto been described, so that it seemed worth investigating rather more closely the variations within one type.

From the non-mucoid type 12 strain 1130, matt and glossy variants were obtained-the matt having $M$ antigen and the glossy having none. After exposure to phage, grossly mucoid variants were obtained from each strain, without changing the $M$ antigen content. The four variants were tested for mouse virulence (Table 8 ). Clearly the matt mucoid variant was the most, and the non-mucoid glossy strain the least virulent. The parent, non-mucoid matt strain and the mucoid glossy seemed approximately equal in their lethal effect. It is interesting to note that in this instance the ability to produce hyaluronic acid enhanced virulence as much as the possession of $\mathbf{M}$ antigen.

Table 8. Mouse-virulence tests on matt and glossy variants of strain 1130, before and after exposure to phage

\begin{tabular}{|c|c|c|c|c|c|c|c|c|c|}
\hline \multirow[b]{2}{*}{$\begin{array}{l}\text { Colonial } \\
\text { variant }\end{array}$} & \multirow[b]{2}{*}{$\begin{array}{c}\mathbf{M} \\
\text { antigen }\end{array}$} & \multirow[b]{2}{*}{$\begin{array}{c}\text { Mucoid } \\
\text { colony }\end{array}$} & \multicolumn{6}{|c|}{$\begin{array}{l}\text { Deaths within } 48 \mathrm{hr} \text {. among mice in } \\
\text { each group of } 10 \text { receiving } 0.5 \mathrm{ml} \text {. } \\
\text { culture diluted }\end{array}$} & \multirow[b]{2}{*}{$\begin{array}{c}\text { Approx. } \\
\text { LD50 }\end{array}$} \\
\hline & & & Nil & $10^{-1}$ & $10^{-2}$ & $10^{-3}$ & $10^{-4}$ & $10^{-5}$ & \\
\hline Glossy & - & - & 9 & 1 & 0 & 0 & 0 & - & 11200 \\
\hline $\begin{array}{l}\text { Glossy phage } \\
\text { survivor }\end{array}$ & - & + & 10 & 9 & $\mathbf{0}$ & 2 & $\mathbf{0}$ & 一 & 355 \\
\hline Matt & + & - & 10 & 10 & 9 & 6 & - & - & 100 \\
\hline $\begin{array}{l}\text { Matt phage } \\
\text { survivor }\end{array}$ & ++ & + & 10 & 10 & 10 & 10 & 10 & 10 & $0 \cdot 6$ \\
\hline
\end{tabular}

Ability to grow in human blood. Although most strains of group A streptococci isolated from acute cases of disease are avirulent for mice they are usually able to grow readily in normal human blood. A number of the parent strains and their phage survivors have been tested for growth in blood, since this might be a better guide to human virulence than the ability to kill mice. Some of the parent strains grew readily, but of those that did not do so, all gave phage-surviving variants which were able to grow (Table 9). The four variants of 1130 used in the mouse virulence tests were also tested in normal blood; only the matt mucoid strain was able to multiply. The possession of $\mathbf{M}$ substance alone or capsule material alone was not enough to ensure multiplication.

\section{DISCUSSION}

From the work described here it is clear that some active phages can lead to the development of a population of streptococci having two of the characteristics of the most virulent strains-the possession of $M$ antigen and the ability to produce a hyaluronic acid capsule. Though it is accepted that there are other 
features concerned in virulence, these two have been studied in some detail. Estimation of virulence is difficult, for it is known that strains apparently virulent for man are not necessarily virulent for mice and the converse may also be true. However, considering mouse virulence and the ability to overcome the bactericidal power of human blood together, it is reasonable to suppose that a strain at first avirulent by either standard which becomes virulent by both has undergone a change drastic enough to warrant some respect. While those working with Corynebacterium diphtheriae and its phages along the lines suggested by Freeman's original work (1951) suggest that the change may be an induced one (Groman, 1953; Barksdale \& Pappenheimer, 1954), the change observed in streptococci seems most probably to be due to selection. The ease with which some strains can also be made mucoid by mouse passage, the fact that many strains initially yield mucoid and non-mucoid colonies, and also the experiments with multiple sampling, suggest that this must be so.

\section{Table 9. Survival of streptococci in human blood before and after exposure to phage}

Growth from mixture sampled at:

\begin{tabular}{|c|c|c|c|c|c|c|c|}
\hline & & & & & & & \\
\hline & & & & & $\mathrm{hr}$. & & hr. \\
\hline Strain & & Colony & antigen & A & B & A & B \\
\hline Type 12 & $\begin{array}{l}\text { Control } \\
\text { Phage survivor }\end{array}$ & $\begin{array}{l}\text { Non-mucoid } \\
\text { Mucoid }\end{array}$ & $\begin{array}{c}\text { trace } \\
++\end{array}$ & \pm & $\begin{array}{l}++ \\
++\end{array}$ & + & $+\overline{+}+$ \\
\hline Type 5 & $\begin{array}{l}\text { Control } \\
\text { Phage survivor }\end{array}$ & $\begin{array}{l}\text { Non-mucoid } \\
\text { Mucoid }\end{array}$ & $\stackrel{+}{+}$ & $\bar{t}$ & $\stackrel{+}{++}$ & $\begin{array}{c}++ \\
+++\end{array}$ & $\begin{array}{l}+++ \\
++++\end{array}$ \\
\hline Type 30 & $\begin{array}{l}\text { Control } \\
\text { Phage survivor }\end{array}$ & $\begin{array}{l}\text { Mixed } \\
\text { Mucoid }\end{array}$ & $\begin{array}{l}\text { trace } \\
+\end{array}$ & $\overline{+}$ & $+\stackrel{ \pm}{+}+$ & - & $\begin{array}{l}+ \\
++\end{array}$ \\
\hline $\begin{array}{l}1130 \text { glossy, } \\
\text { type } 12\end{array}$ & $\begin{array}{l}\text { Control } \\
\text { Phage survivor }\end{array}$ & $\begin{array}{l}\text { Non-mucoid } \\
\text { Mucoid }\end{array}$ & - & \pm & \pm & $\overline{-}$ & - \\
\hline $\begin{array}{l}1130 \text { matt, } \\
\text { type } 12\end{array}$ & $\begin{array}{l}\text { Control } \\
\text { Phage survivor }\end{array}$ & $\begin{array}{l}\text { Non-mucoid } \\
\text { Mucoid }\end{array}$ & $\stackrel{+}{++}$ & $\begin{array}{l}++ \\
++\end{array}$ & $\begin{array}{c}+++ \\
++++\end{array}$ & $\bar{t}$ & $\begin{array}{c}++ \\
+++\end{array}$ \\
\hline
\end{tabular}

$A=$ inoculum, $0.02 \mathrm{ml}$. of culture diluted $10^{-5} ; \mathrm{B}=$ inoculum, $0.02 \mathrm{ml}$. of culture diluted $10^{-3} ;-=$ no growth; $\pm=1$ to 10 colonies; $+=10$ to 50 colonies; $++=50$ to 200 colonies; $+++=$ more than 200 colonies; $++++=$ continuous sheet of growth.

Whether a selective process of the same sort can take place in vivo is not known and this may repay further investigation. Evans (1933) stated that phage action did not take place in many body fluids, but it seems probable that the addition of hyaluronidase to a system such as she used might allow some lytic activity. It is of interest to recall that Evans, describing experiments where mice infected with group A streptococci were given phage filtrates in an attempt to save them, noted that the phage-treated mice died slightly more rapidly than the untreated controls.

The phages used here were lytic phages which originated from sewage and their true origin is somewhat obscure. None of the strains of streptococci passed through them seemed to become lysogenic, and streptococci recovered from mice infected with phage survivors were not lysogenic nor contaminated 

Journal of General Microbiology, Vol. 12, No. 3

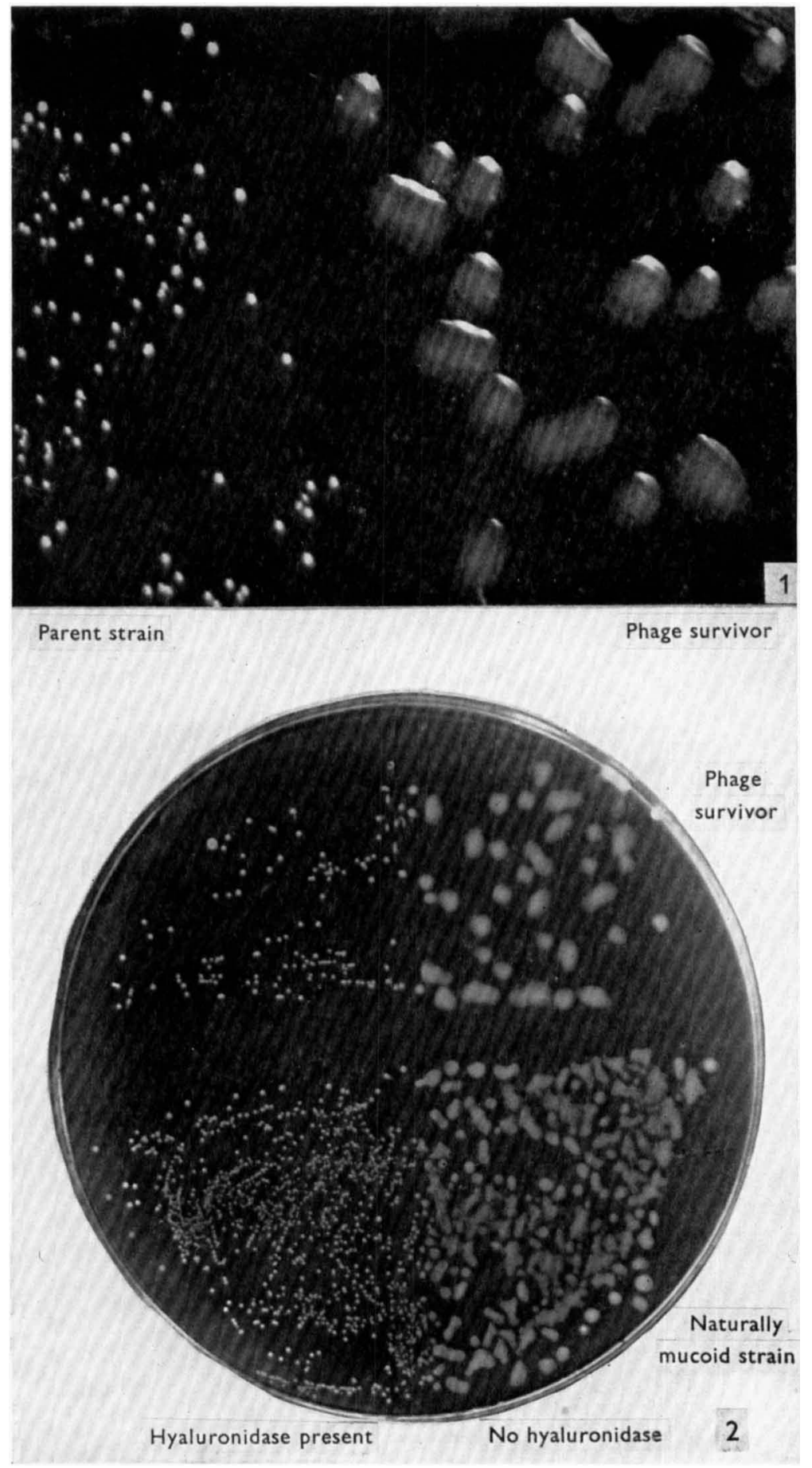

W. R. Maxted-The influence of phage on streptococci. Plate 1

(Facing p. 495) 
with phage. The phage-selected mucoid streptococcal variants were stable when freed of phage, but whether they are stable for the $\mathbf{M}$ antigen for more than about six subcultures in the absence of phage was not tested.

I wish to thank Dr E. S. Anderson and Dr C. C. Spicer for their interest and advice.

\section{REFERENCES}

Barksdale, W. C. \& Pappenheimer Jun., A. M. (1954). Phage-host relationship in diphtheria bacilli. J. Bact. 67, 220.

Evans, A. C. (1933). Inactivation of antistreptococcus bacteriophage by animal fluids. Publ. Hlth. Rep. 48, 411.

Evans, A. C. (1934). Streptococcus bacteriophage: A study of four serological types. Publ. Hlth. Rep. 49, 1386.

Evans, A. C. (1940). The potency of nascent streptococcus bacteriophage $B$. J. Bact. 39, 597 .

Evans, A. C. \& Sockrider, E. M. (1942). Another serological type of streptococcic bacteriophage. J. Bact. 44, 211.

Faber, V. \& Rosendal, K. (1954). Streptococcal hyaluronidase II. Acta path. microbiol. scand. 35, 159.

Freeman, V. J. (1951). Studies on the virulence of bacteriophage infected strains of Corynebacterium diphtheriae. J. Bact. 61, 675.

Griffith, F. (1934). The serological classification of Streptococcus pyogenes. J. Hyg., Camb. 34, 542.

Groman, W. B. (1953). Evidence for the induced nature of the change from nontoxigenic to toxigenicity in Corynebacterium diphtheriae as a result of exposure to specific bacteriophage. J. Bact. 66, 184.

LeDERBERG, J. \& LEDERBERG, E. M. (1952). Replica plating and indirect selection of bacterial mutants. J. Bact. 63, 399.

Luria, S. E. \& Delbrück, M. (1943). Mutations of bacteria from virus sensitivity to virus resistance. Genetics, $28,491$.

MaXted, W. R. (1952). Enhancement of streptococcal bacteriophage lysis by hyaluronidase. Nature, Lond. 170, 1020.

Newcombe, H. B. (1949). Origin of bacterial variants. Nature, Lond. 164, 150.

Schwartzman, G. (1927). Studies on streptococcus bacteriophage. J. exp. Med. 46, 497.

SwiFT, H. F., Wilson, A. T. \& Lancefield, R. (1943). Typing group A haemolytic streptococci by $\mathrm{M}$ precipitin reactions in capillary pipettes. J. exp. Med. 78, 127.

\section{EXPLANATION OF PLATE}

Fig. 1. Mucoid colonies of phage survivor, $\times 4$.

Fig. 2. Effect of hyaluronidase on colonies of naturally mucoid and phage-survivor mucoid strains. $\times 1$. 